\title{
Dialectic of Mass Culture: How Culture Industry Shaped the Masses
}

\author{
Yijia Shi \\ School of Humanities and Social Sciences, Xi'an Jiaotong University (XJTU), Xi'an, China \\ *Corresponding author. Email: jennifer_yijia_shi@163.com
}

\begin{abstract}
This essay uses Horkheimer and Adorno's work on the culture industry to analyze how the culture industry shaped the masses from its historical cause and how it keeps coming into effect. While promoting individual awakening, Enlightenment created a system of totality. According to this logic, the cultural industry not only turns culture and art into commodities through capital manufacture, but also affects consumers with its productions. To a certain extent, this process makes consumers lose their self-awakening, and this result is contrary to the Enlightenment.
\end{abstract}

Keywords: culture industry, the masses, Enlightenment, totality, self-awakening

\section{INTRODUCTION}

"Culture industry" first appeared in the book Dialectic of Enlightenment, which published in Amsterdam in 1947. Adorno said in his essay Culture Industry Reconsidered that in the first draft of Dialectic of Enlightenment they used "mass culture", and then they replaced that expression with "culture industry" to distinguish it from the contemporary form of popular art, which refers to a culture that arises spontaneously from the mass themselves. In general, culture industry precisely refers to "products which are tailored for consumption by masses, and which to a great extent determine the nature of that consumption, are manufactured more or less according to plan [1]."

The culture industry thesis is essentially a critique of the sameness of mass media such as movies, television, and popular music [2]. Horkheimer and Adorno maintained that the diversity of content in mass media is illusory, which means culture industry media had presented standardized experiences that are the same for every viewer [3]. The variety of texts and superficial differences give the false appearance of uniqueness [3]. This sameness is a consequence of the economic system that produces these texts, distributes them, situates them concerning other activities, and deprives them of the power to challenge the status quo [4]. In this case, the culture industry will stifle political awakening and discourage creativity by cultivating a passive audience. The culture industry objectifies the human as a politically apathetic, passive consumer.
Mainly, the arguments of the culture industry focus on how the culture industry is supposed to work on masses. Adorno and Horkheimer asked in the spirit of true Enlightenment: what makes masses into masses [5]? Following this, this essay will focus on this question and argue how culture industry shaped the masses from its historical cause and how it keeps coming into effect.

\section{THE HISTORICAL CAUSE OF CULTURE INDUSTRY: A CRISIS BROUGHT ON BY THE TRIUMPH OF ENLIGHTENMENT}

The culture industry cannot be made possible without a crisis brought on by the triumph of Enlightenment. Adorno and Horkheimer begin the Concept of Enlightenment with this definition; Enlightenment, understood in the widest sense as the advance of thought has always aimed at liberating human beings from fear and installing them as masters. Yet the wholly enlightened earth is radiant with triumphant calamity. Enlightenment's program was the disenchantment of the world. It wanted to dispel the myth, to overthrow fantasy with knowledge [3].

As it says, the disenchanting of the world began with the elimination of the myth. Enlightenment is against myth but in essence Enlightenment is based on myth. In the past, people were controlled by nature, but the Enlightenment thinkers interpreted nature from the subject's perspective. The Enlightenment is the 
awakening man who then ruled the natural world through technology and instrumental reason. There's no alternative to Enlightenment. People in modernity can imagine in respectable terms that all forms of knowledge are pulled into the Enlightenment mold, are pressured to conform to the scientific model of understanding. No one can escape from this power system, even the awakening man himself. There's nothing outside the Enlightenment. So, Enlightenment became the new myth.

After the Second World War, scholars had kept their eyes on the destructive power of this reason, the high expansion of violence, which is the terrifying totalitarianism and the uncontrolled technology. They conspired to make the awakening individual melt into the great totality again. A system of Enlightenment that had become ever tighter in its organization, more global in its reach, and more potent in its ability to control people. This nefarious globalization as a product of the Enlightenment. Modernity and Enlightenment joined hands to create a new universal myth that entrapped us with its appeal while controlling us and diminishing our freedom at every step.

\section{THE MANIPULATION OF THE MASSES BY THE CULTURE INDUSTRY}

\subsection{Production system of the culture industry}

In 1933, Theodor W. Adorno was banned from teaching in Germany and had to move to the United States. The mass production of goods and a pervasive entertainment culture there led him to realize that the Enlightenment control not only accomplished by means of violent but has also realized in a cunning way to erodes culture and our everyday life, which is called the culture industry.

Adorno argued culture industry is essentially the Enlightenment as mass deception. It means false and fake Enlightenment; individuals are guided to make choices that are seemingly free which are in essence designed [3].

The culture industry produced under the logic of capitalization, it is a kind of industry that is composed of replication and consumption. The reproduction technology enables the unique art works to be reproduced in large numbers, the production of culture and art adopt to the industrial mold. And the communications and media allow these replicas to widely disseminate. The result is that the high art lost what Walter Benjamin called authenticity, which means its presence in time and space, its unique existence at the place it happens to be [6]. And then the high art lost its sacredness. It will be hard to distinguish it from the ordinary goods. "High art, then is not for Adorno some repository of truth; if the truth lies anywhere, it lies precisely in the division between it and the culture industry, in the non-whole to which these two dissevered halves of cultural production add up [1]."

In technological terms, millions have participated in the reproduction and consumption. The contrast between the few production centers and many widely dispersed consumptions points out the demand organization and planning by management [3]

It means culture, as a business and industry, is controlled by the organizational rules and limited in the same scheme, which is offered by the manufacturers.

"Films radio and magazines make up a uniform system as a whole and in every part. Even the aesthetic activities of political opposites are one in their enthusiastic obedience to the rhythm of the iron system" [7] a more efficient reproduction, and the only difference is the nuance of the details, which used as a personal distinction. Then all attention is distracted by disjointed interests and nowhere to find the once intense aesthetic. Furthermore, values such as beauty and morality also dispelled and reduced to differences in personality and preferences. And this formulaic style does not change over time but always remains the same. This quality of "ever-sameness" does not apply to the surface content of popular culture, which is constantly changing, but to its form, to the structures that hold everything in place [2]. In this way, there is no opportunity for resistance because in the culture industry, any opposition can be considered as only a narrow personal preference.

Thus, the culture industry achieves a universal and effective control. All syntax and language are provided by the producer and is passively accepted by the consumer, who are banned from expressing valid or forceful objections or any critical ideas. Consumers have believed that cultural products are all produced according to their own needs. They are all following producers' will. By dispelling reflective and critical opinions, the culture industry also provides another seemingly fair method of evaluation, which is the technological and calculating model. The ranking lists and box office became the new myths and authorities, where to hit the top only means it brings more benefits. The Matthew effect kept fulfilling, and the circulation completely blocked and stopped the new birth. Because if anything new wants to come into the public view, it must first be examined and evaluated by the industrial system. Otherwise, it cannot get a considerable price and reputation and cannot survive in the cruel market. Then the new even cannot be widely disseminated and be genuinely appreciated. The feature of the mass culture is the exclusion of the new. All the styles it shows are only obedience to the social hierarchy. All personalities are deception and "when art set itself free from church, state and patron to become a 'private' affair on the market [1]." Then the triumph of totality 
comes into reality again. The culture industry enjoys a double victory: the truth it extinguishes without it can reproduce at will as a lie within [3].

\subsection{The influence of cultural industry on audience psychology}

The culture industry constantly promises to consumers and continually deceives them. It has always whetted the appetite with eye-catching gimmicks, but the plots and performances it offers are nothing new. Moreover, it even refuses to take responsibility. The culture industry constantly argues that the cheap culture is produced for audience's need, and what those vulgar cultural products reflect is the degradation of the audience's aesthetic. And then it is on the contrary the audience should be responsible for being not able to enjoy the fabulous or even the qualified culture.

Thus, the consumer is always in a low and passive position in the system of the cultural industry. At the same time, they blindly believed in what controls them. For example, Donald Duck who has been beaten by life again and again, reflects their living conditions. That shows ordinary people can never have the chance to obtain outstanding achievements in their life. They are not allowed to express the reflective and critical ideas and are even deprived of subjectivity and agency. "The more intensely and flawlessly (the producer's) techniques duplicate empirical objects, the easier it is today for the illusion to prevail that the outside world is the straightforward continuation of that presented on the screen... Real-life is becoming indistinguishable from the movies [7]".

In the culture industry, happiness and sadness have different connotations; laughter and crying have become the echo of power. Happiness means always nodding in agreement and being unconditional optimistic at everything, which essentially means that there is nothing that deserved to be taken seriously. It makes the individual apathetic and numb and isolates the individual from the overall social process and the great narration. In the name of humor, it allows the individual not to dwell on his own tragedy but rather to rejoice in acquiring of the virtues of joy in suffering. Thus, everyone surrenders and no longer has any expectation or hope for happiness then like this omnipotent society, everyone is filled with joy and hope.

The tragedy is completely hollowed out. Tragedy has become incompetent and self-deserved. It has lost the power of purifying as it has in ancient times. For example, heroes in movies and literature became to have all kinds of flaws. When they suffered a blow or failure, the audience will intend to feel more pity or regret, rather than indignant or inspiration when the perfect classic heroes suffered a setback. The power of tragedy is then so easy to dispel by a fake personality. Thus, in this society, the individual is wholly faded into the totality. Everyone is the same; everyone is replaceable. Success does not depend on individual's intelligence anymore but on gifts of the capital structure. The plots that a character wins the lottery and make a great fortune overnight are so beloved by the audience. It gives a illusion of hope to ordinary people. They are generally controlled and believe everyone has the chance to be chosen and to succeed. All consumers of the culture industry escape from is the possibility of imagining another life: "It is not because they turn their back on washed out existence that escape films are so disgusting, but because they do not do so energetically enough, because they are themselves just as washed-out, because the satisfactions they fake coincide with the ignominy of reality, of denial. The dreams have no dream [8]".

\section{CONCLUSION}

In conclusion, in the system of the culture industry, mass culture is not for the masses but to adopt the means of quantification and replication to achieve the aim of mass propaganda. The culture industry produced on demand, but it doesn't create spiritual works of art. What it makes is only the commodity for the infinite surplus value. Therefore, mass culture, or to say pop culture, is a commodity rather than an art. The mass culture does not realize the communication between the culture and its audience, but the one-way indoctrination, in this process the mass is a veritable passive. From the content point of view, popular culture vulgarizes the works of art and reduces the classics to entertainment Mass culture has reconciled with reality creating entertainment, rather than reflecting and criticizing life.

\section{REFERENCES}

[1] T.W. Adorno (1991), The Culture Industry: Selected Essays on Mass Culture, ed. J.M. Bernstein, London: Routledge

[2] Gunster, S. (2000), Revisiting the culture industry Thesis: Mass culture

and the commodity form. Cultural Critique 45: 4070 .

[3] Horkheimer, M., and T. Adorno. (1969) Dialectic of enlightenment. New York, NY: Continuum.

[4] Schulzke, M. (2014), The Virtual Culture Industry: Work and Play in Virtual Worlds. The Information Society, 36: 20-30.

[5] Adorno, Theodor. (1992), "Freudian Theory and the Pattern of Fascist Propaganda." In The Essential Frankfurt School Reader, ed. Andrew Arato and Eike Gebhardt, New York: Continuum: 118-37. 
[6] Walter Benjamin. (1963), The Artwork of the Machine Replication.

[7] Adorno, Theodor. (1993), "Theory of Pseudo Culture." Trans. Deborah Cook. Telos 95 (spring): 15-38.
[8] Adorno, Theodor. (1974), Minima Moralia. Trans. E. F. N. Jephcott. London: New Left Books. 